\title{
Living Constitution in Indonesia: The Study of Constitutional Changes Without A Formal Amendment
}

\author{
Muhammad Addi Fauzani \\ Islamic University of Indonesia, Indonesia \\ addifauz@gmail.com
}

Nur Aqmarina Deladetama

Islamic University of Indonesia, Indonesia

deladetama8@gmail.com

Muhammad Basrun

Islamic University of Indonesia, Indonesia

muhammadbasrun215@gmail.com

\author{
Muhammad Khoirul Anam \\ Islamic University of Indonesia, Indonesia \\ muhammadkhoirulanam08@gmail.com
}

\begin{abstract}
The discussion regarding the living constitution in Indonesia has been increasingly important. The importance of this discussion deals with to the extent it has developed, particularly after Indonesia's constitutional amendment from 1999 to 2002. In particular, the current study of constitutional change in Indonesia, as a result of constitutional amendment during Reformation, adds an emphasis on its change without a formal amendment. Thus, this paper will discuss the urgency of enforcing the amended 1945 Constitution in the lens of the living constitution and how to uphold it through the living constitution. This study uses a doctrinal research and, in examining the case, it uses the statutory and conceptual approaches. The result of the study shows that the urgency of upholding the constitution through the living constitution relies on the concept of the living constitution that can dynamize the 1945 Constitution. In response to difficulties to formally amend the 1945 Constitution that depends on political will and rigid juridical condition, there should be a shift in the method of interpretation of the constitution by the Constitutional Court judges, from originalism to the living constitution. The enforcement of the 1945 Constitution through the living constitution can apply the constitutional convention and the interpretation by constitutional judges. This study suggests that the Government and the House of Representatives and other relevant state institutions can use the living constitution, by taking into account the constitutional convention is a source in the organization of the state to patch up the weaknesses of the constitution.
\end{abstract}

KEYWORDS: Living Constitution, Constitutional Revision, Formal Amendment.

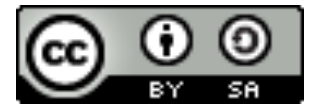

Copyright $\odot 2020$ by Author(s)

This work is licensed under a Creative Commons Attribution-ShareAlike 4.0 International License. All writings published in this journal are personal views of the authors and do not represent the views of this journal and the author's affiliated institutions. 


\section{HOW TO CITE:}

Fauzani, Muhammad Addi et al. "Living Constitution in Indonesia: The Study of Constitutional Changes without A Formal Amendment" (2020) 7:1 Lentera Hukum 69-84

Submitted: October 02, 2019 Revised: October 18, 2019 Accepted: January 04, 2020

\section{INTRODUCTION}

Differences in the understanding of the constitution motivate this research. First, the constitution is only understood as a written constitution. Second, by citing Herman Heller's view, there is a variety of the understanding of the constitution, which (a) reflects political life in society as a reality and is not yet a constitution in the legal sense; (b) the political life in the society is sought by the legal elements through abstraction then becomes the unity of the rule of law; and (c) there is a need to write the constitution in a manuscript then the rule of law is written in a manuscript called the constitution. ${ }^{1}$ So, according to Jimly Asshiddiqie, Undang-Undang Dasar or the Basic Law is only part of the constitution, namely the written constitution. ${ }^{2}$ This narrower understanding of the constitution emerges partly by the influence of codification that requires all legal regulations to be made in written form. ${ }^{3}$

In the context of the Indonesian constitution, the 1945 Constitution of the Republic of Indonesia (1945 Constitution) is a written constitution which is the highest law in Indonesia. However, it must be admitted that the 1945 Constitution, even though it was amended in 1999, 2000, 2001, and 2002, still has considerable weaknesses. Legal scholars like HAS Natabaya, for example, argue that the results of the amendment were "congenital defects. ${ }^{4}$ Thus, it has worsened the quality of the Indonesian constitution as it surely accounts that the 1945 Constitution classified as the written constitution has its shortcomings on its difficulties to keep up with the times and accommodate a sense of justice.

Weaknesses in the 1945 Constitution should not be ignored because the constitution has several values. Such values emerge as the result of an evaluation of the application of the constitutional norm. Karl Loewenstein outlines three kinds of values embedded in a constitution as the first normative value. The constitution has normative value if it is understood, acknowledged, and obeyed by legal subjects attached to it. If the constitution is partly or wholly not used in the administration of the country, the constitution is nominal whereas it is said to have semantic value if the constitution is only used as jargon or instrument of power and a means of justifying state policy. ${ }^{5}$ The

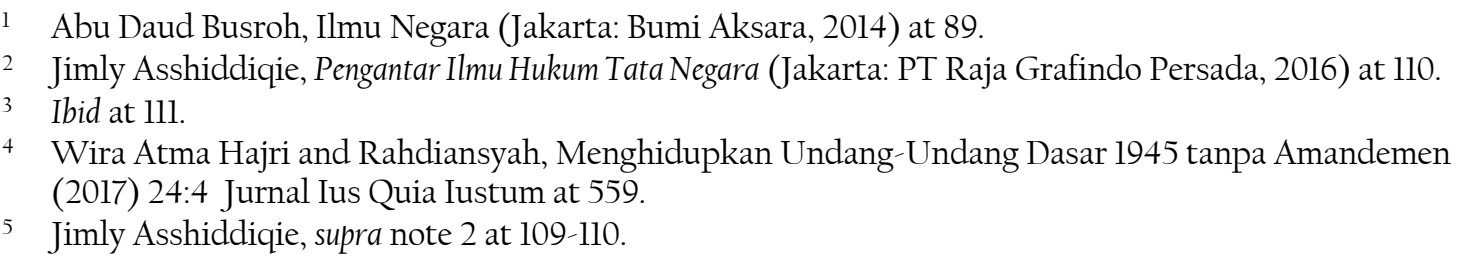


1945 Constitution may contain semantic values in terms of achieving the goals of the country if, in its constitutional creation, it has many weaknesses.

By referring to the weaknesses in the 1945 Constitution, it is necessary to initiate the idea of enforcement of the 1945 Constitution through the unwritten constitution. It must also be acknowledged that there is an unwritten constitution that is often known as the living constitution, a law that develops in living values in the community's legal awareness. ${ }^{6}$ This paper will discuss two main issues. First, this paper discusses the urgency of upholding the 1945 Constitution through the living constitution. Secondly, this paper examines efforts to uphold the 1945 Constitution through the living constitution.

\section{A NEED TO APPLY THE LIVING CONSTITUTION IN INDONESIA}

\section{A. Living Constitution Used for Dynamizing the 1945 Constitution}

Constitution, as a written constitution, is considered as the basic law and the highest law in administering a country. ${ }^{7}$ It is in line with Hans Kelsen that argues the hierarchical structure of the legal order of the state is roughly as follows: presupposing the basic norm, the constitution is the highest level within national law. ${ }^{8}$ Hans Kelsen's opinion regarding the constitution has two positions: first, the constitution is based on the law or basic norms. Second, the constitution has the highest legal status. The derivative of this concept is about the hierarchy of laws and regulations. Hans Kelsen's concept has been subsequently adopted in Indonesia. It refers to the Legislative Drafting Act that outlines the hierarchy of laws in Indonesia by including several common regulations and the TAP MPR (People's Consultative Assembly's decrees). Until now, all these regulations should refer to the 1945 Constitution as the highest law.

The above-mentioned statement is a consequence of the adoption of codification, which is very identical to positivism. Positivism is a school of philosophical understanding that developed in Continental Europe, especially in France with two well-known exponents, Henry Saint Simon (1760-1825), and August Comte (17981857), Positivism is an understanding that demands methodology to be considered to find the truth should treat reality as something that exists as an object, in the science of law positivism means that legal theory only has to do with positive law. ${ }^{9}$ The School of Positivism regards law as neutral and objective, which is different from politics, culture, morals. However, the process of formation is not random but rational and logical.

\footnotetext{
Jimly Asshiddiqie, Konstitusi dan Konstitusionalisme (Jakarta: Sinar Grafika, 2011) at 255. Jimly Asshiddiqie, Hukum Tata Negara dan Pilar-Pilar Demokrasi (Jakarta: Press Constitution, 2005) at 77. Hans Kelsen, Teori Umum Tentang Hukum dan Negara, Translator: Raisul Muttaqien, VI Printing (Bandung: Nusa Media, 2011) at 124.

9 Irham Nugroho, Positivisme Auguste Comte: Analisa Epistimologis dan Nilai Etisnya terhadap Sains (2016) 9:2 Jurnal Cakrawala at 169-170.
} 
According to Unger, each particular legal method will produce certain legal choices. ${ }^{10}$ Legal science itself does not discuss whether positive law is good or bad, nor does it discuss the effectiveness of law in society. ${ }^{11}$ Because the purpose of the formation of a rule is to be obeyed by the community.

One weakness of the written constitution or in Indonesia commonly called Undang-Undang Dasar is the limited scope of the constitutional text because the constitution, according to Wheare, is a political resultant that reflects the political, economic, and social forces that were running at the time of its formation. ${ }^{12}$ The material in it does not accommodate the development of the age and thought, therefore the supporting regulations that emerge live and are recognized but not written as a constitution that existed from the start as rules. Some apparent weaknesses of the 1945 Constitution are the weak authority of the Regional Representative Council (DPD) compared to the People's Representative Council (DPR). Even in the 1945 Constitution that governs the DPD Article, there is only one Article. ${ }^{13}$ The DPD legitimately tends to be strong because it is directly elected by the people in the region, but the strength of this legitimacy is contrary to its authority, which tends to be minimalist, especially when compared to the authority of the DPR. The DPD does not have as much legislative authority as the House of Councillors in Japan. The authority to form laws owned by the House of Councillors reaches the approval stage, while the DPD only reaches the discussion stage. ${ }^{14}$ Plus, the DPD is not only weakly institutionally but personally weak. If a member of the DPR obtains a guarantee of immunity in the 1945 Constitution, this does not apply to members of the DPD. ${ }^{15}$

The weak authority of the DPD before the DPR arguably ignores the pivotal role DPD, as an internal control of the parliament. Following Sartori's opinion, "two eyes are better than one eye, "which means that two eyes are better than one eye, ${ }^{16}$ it has the implied meaning that the two chambers in a parliament should have a check and balance function. Therefore, the Indonesian parliamentary system in the future should lead to a bicameral parliamentary system under what the DPD wants. However, it must also be remembered that the Indonesian parliamentary system should not lead to a bicameral parliamentary, which is equally strong (perfect bicameralism). ${ }^{17}$ Indonesia cannot implement a system of perfect bicameralism because this system is identical to the form of a federal state, and there are still political groups that oppose this system. Besides,

\footnotetext{
10 Donny Danardono, Critical Legal Study: The Position of Terror and Criticism, online: 〈https://www.Academia.edu/26063461/Positivisme_Hukum_Vs_Critical_Legal_Studies_l〉.

Il Soetandyo, Hukum: Paradigma, Metode, dan Dinamika Masalahnya (Jakarta: ELSAM and HUMA, 2002) at 95.

12 Mahfud MD, Politik Hukum (Jakarta: PT Raja Grafindo Persada, 2010) at 10.

13 Denny Indrayana, Antara Ada dan Tiada (Bogor: Grafika Mardi Yuana, 2008) at 298.

14 Article 59 of the Constitution of Japan.

15 Ibid at 299.

16 Mahfud MD, Perdebatan Hukum Tata Negara Pasca Amandemen (Jakarta: PT Raja Grafindo Persada, Second Printing, 2011) at 69.

17 Denny Indrayana, supra note 13 at 306.
} 
perfect bicameralism leads to a deadlock in the political process. ${ }^{18}$ Not only that, ten other proposals submitted by the DPD to change the 1945 Constitution are strengthening the presidential system, strengthening representative institutions, strengthening regional autonomy, reconstructing national and regional elections, optimizing the roles and relations of Judicial Power (Constitutional Court, Supreme Court, and the Judicial Commission), ${ }^{19}$ the forum previlegiatum for public officials, the addition of articles on Human Rights (HAM), the independent state commission, and the sharpening of the chapter on education and the national economy. ${ }^{20}$

Based on the weaknesses of the 1945 Constitution, which is formally a written constitution and materially still has substantial weaknesses, then, in addition to the 1945 Constitution, must also recognize an unwritten constitution or living constitution. Theoretically, the nature of the written constitution is flexible and rigid. That is, if no needed special process is to amend the constitution, it is called flexible if necessary, the process is called rigid. ${ }^{21}$ According to Jimly Asshiddiqie, in addition to the written constitution, it must also be recognized that there is an unwritten constitution, which develops in living values in the awareness of community law or living constitution. ${ }^{22}$ A living constitution is not only in a formal (written) form but is capable of realizing a good government for a sovereign society as envisioned. The constitution can develop and be developed in line with the changes that occur. In current practice, changes seem elastic and less aspirational because the constitution does not emerge from a vacuum. ${ }^{23}$

The living constitution can be useful to dynamize the 1945 Constitution, namely by filling in the rules that have not been regulated in the 1945 Constitution or can also make changes to the 1945 Constitution through non-formal changes. Because living constitution as one form of critical legal studies on positivistic constitutional. Critical legal studies is the thinking that accommodates Marxist form of thinking, but also liberal-radical and post-modernism, which considers the law is not separate from politics. ${ }^{24}$ Non-formal changes can be through the decision of the Constitutional Court, which is interpreted by the constitutional judge and through the constitutional convention. It is consistent with what was stated by Wheare that constitutional changes could happen in two ways. ${ }^{25}$ First, constitutional changes stipulated in the constitution are called formal amendments. Second, constitutional changes can be made through informal means, namely by using some primary forces, judicial interpretation, and customs and conventions. Thus, the living constitution that is

\footnotetext{
18 Ibid at 307.

19 Jimly Asshiddiqie, supra note 7 at 91-97.

20 Denny Indrayana, supra note 13 at 307.

21 K.C. Wheare, Konstitusi-Konstitusi Modern (Surabaya: Pustaka Eureka, 2005) at 24.

22 Jimly Asshiddiqie, supra note 6.

23 A. Ahsin Thohari, Membayangkan Living Constitution, online: 〈www.perp library.bappenas.go.id〉.

24 Donny Danardono, Critical Legal Studies: Position Theory and Criticism (2015) 14:1 Jurnal Kisi Hukum.

25 K.C. Wheare, supra note 21 at 23-50.
} 
adhered to can become the basic rules of the administrative state outside the Basic Law through non-formal changes, which is not only nominal or semantic value. He really can live in the middle of society as a normative reference. Because actually, the law has a static, dynamic nature such as silence for certainty but moves to follow changes in society to meet the needs of social reality. ${ }^{26}$

\section{B. The Problems of Rigidity on the Formal Constitutional Amendment in Indonesia}

Upholding the 1945 Constitution through the living constitution is also caused by the difficulties to amend the 1945 Constitution formally. The main factor that significantly changes the constitution is the various (renewal) conditions in society. Indeed, the democratization spurs the implementation of the welfare state, including changes in the pattern and the economic system as a result of industrialization, following the advancement of science and technology can be a force driving such a renewal. ${ }^{27}$

The amendment to the 1945 Constitution does comprise not only legal, but also political aspects. Then, no matter how good the proposed amendment submitted by MPR members from DPD members, if the legal aspect in this case the change procedure is too rigid, impractical, or almost "impossible" to do the change, and the political aspect is not supported by the power of the majority, as well as extraordinary momentum, the proposed amendment was only limited to black on white paper that never applied. It is happening now with proposals submitted by MPR members from the DPD members.

\section{Rigid mechanism to according to Article 37 of the 1945 Constitution}

Amendments to the 1945 Constitution is considered rigid or difficult because it needs to go through certain procedures not to facilitate changes, but rather to complicate changes or limit changes. The targets to be addressed through various procedures for change are based on the opinion of Wheare with the aims: (a) the changes are made with and conscious consideration, not arbitrarily; (b) the people have the opportunity to give their opinions before changes are actually made; (c) state and central government power in the federal state is not changed unilaterally; and (d) the rights of individual communities such as minorities in terms of religion, language and culture are guaranteed. ${ }^{28}$

Elly Chaidir has the same view regarding the process of amending the 1945 Constitution by complicating the process of change. ${ }^{29}$ Because the constitution contains basic norms, so when it is too easy to change, it will have a significant impact on the legislation under it. Of course, the laws and regulations under the constitution must be adjusted again to the new norms of the constitution.

Article 37 of the 1945 Constitution states that:

26 Ilham Yuli, Rekonstruksi Hukum dan Ketanegaraan Indonesia (Yogyakarta: UII Press, 2016) at 13.

27 Ni'matul Huda, Perkembangan Hukum Tata Negara (Yogyakarta: UII Press, 2014) at 66.

28 Ellydar Chaidir \& Sudi Fahmi, Hukum Perbandingan Konstitusi (Yogyakarta: Total Media, 2010) at 53.

29 Ibid at 53. 
(1) Proposed amendments to the articles of the Constitution can be scheduled in a session of the People's Consultative Assembly if submitted by at least $1 / 3$ of the total members of the People's Consultative Assembly.

(2) Each proposal for an amendment to the articles of the Constitution is submitted in writing and clearly indicated the proposed part to be changed along with the reasons.

(3) To amend the articles of the Constitution, the People's Consultative Assembly Session is attended by at least $2 / 3$ of the members of the People's Consultative Assembly.

(4) The decision to amend the articles of the Constitution was made with the approval of at least 50 percent plus one member from all members of the People's Consultative Assembly.

(5) Specifically, the form of the Unitary Republic of Indonesia cannot be changed. ${ }^{30}$

By taking into account the said procedures for amending the 1945 Constitution, it asserts the motivation by which the Constitution does not only aim for not being too easy to amend (rigid) but also it "refuses" for possible amendment (over rigid). Therefore, it is only natural that the amendment fifth that was discussed by MPR members from DPD members would remain a discourse. Because in terms of the number of membership, MPR members from DPD members are not sufficient conditions for amendments constitutional. Not to the point of discussion or approval, only the proposal stage of MPR members from DPD members was also hampered by the formal procedure of Article 37 of the 1945 Constitution. To propose changes, a required $1 / 3$ of the total number of MPR members is. Because the number of MPR members in this period is 692, it means that for the proposed changes, 232 MPR members are needed, while the number of DPD members is only 132, and the remaining 560 are DPR members. ${ }^{31}$

2. The amendment depends on the political powers

Members of the People's Consultative Assembly (MPR) from DPD members need the support of the majority of DPR members who are also MPR members. Article 2 paragraph (1) of the 1945 Constitution states that The People's Consultative Assembly consists of members of the People's Legislative Assembly, and members of the Regional Representative Council elected through general elections and regulated further by law. ${ }^{32}$ However, MPR members come from DPR members that do not support it.

The rejection of MPR members from DPR members for the fifth amendment is more in order to maintain the constitutionally established authority they have in the field of legislation. On the other hand, Article 20 paragraph (1) of the 1945 Constitution

Article 37 of the 1945 Constitution.

Wira Atma Hajri and Rahdiansyah, supra note 4 at 563.

Article 2 paragraph (1) of the 1945 Constitution. 
outlines the House of Representatives holds power to form laws. ${ }^{33}$ While proposals submitted by MPR members from DPD members, one of which is the strengthening of the DPD in the field of legislation. Unlike so far, the DPD is only involved in the proposal and discussion stages, not in the approval stage. The approval stage is the most decisive or crucial stage in the field of legislation.

If the parliament members respond to the fifth amendment proposal by stating that it is not yet time to make further amendments, in fact, it is a form of indirect rejection. ${ }^{34}$ The DPR's treatment to the DPD so far is quite a sign that the DPR does not accept if the DPD has full authority in the field of legislation such as the DPR and the President. Instead of the full legislation, the DPD has a pseudo-legislative function, which is often undermined by the DPR. It is clearly seen in Law Number 27 of 2009 concerning the MPR, DPR, DPD, and DPRD, Law Number 12 of 2011 concerning Formation of Laws and Regulations, and Law Number 17 of 2014 concerning MPR, DPR, DPD, and DPRD which were then straightened out by MK Decision Number 92/PUU-X/2012 and the Constitutional Court's Decision Number 79/PUU-XII/2014. Even so, the legislative authority of the DPD is still not equal to the DPR. ${ }^{35}$

In addition, the episode is needed to change the written constitution. Amendments to the first, second, third, and fourth 1945 Constitution starting from 1999-2002 will not occur if they are not supported by the momentum, especially the economic crisis as a result of the collapse of the Suharto regime in May 21, 1998. ${ }^{36}$ Elster and Mc Whinney support this argument, and as quoted by Denny for which political turmoil is needed to reform a constitution because it arises as a pressure that demands changes to the constitution when a country's constitution is no longer congruent with social values so that it is increasingly difficult to make changes to the 1945 Constitution. ${ }^{37}$ The 1945 Constitution it is increasingly difficult to change to the 1945 Constitution, the only way is to uphold the constitution through a living constitution that is accommodated through filling out the rules governing the unregulated state and conducting non-formal amendments.

\section{Shifting the Method of Interpretation by the Constitutional Court: from Originalism Towards the Living Constitution}

Astim Riyanto argues that the constitution as the Basic Law should be the basic rules in the administration of the state." Basic Law consists of written fundamental law and unwritten fundamental law. ${ }^{38}$ Written basic law becomes fundamental rules in the administration of the state, while basic unwritten law is the basic rules which arise and are maintained in the practice of administering the state even if not written. On the

33 Article 20 paragraph (l) of the 1945 Constitution.

34 Tempo.co, DPR Tolak hak Veto, (2006) online: ‘https://nasional.tempo.co/read/79009/dpr-tolak-hakveto-dpd.

35 Wira Atma Hajri and Rahdiansyah, supra note 4 at 566.

36 Ibid at 566.

37 Denny Indrayana, supra note 13.

38 Astim Riyanto, Teori Konstitusi (Bandung: Yapemdo, 2003) at 12. 
other hand, the constitution in the strict sense is only referring to the Basic Law, which applies as the highest law. ${ }^{39}$

Legal scholars like Manunggal K. Wardaya argue that the Court gave contextual meaning to Undang-Undang Dasar with sociological and teleological interpretations. Thus, the constitutional text is interpreted to meet a sense of justice. According to him, the decision affirming the power of the Constitutional Court in examining the government regulation in lieu of law or Peraturan Peraturan Pengganti Undang-Undang (Perpu) indicated that the Court imposed the 1945 Constitution as a living constitution. ${ }^{40}$ The Constitutional Court, borrowing Liu, Karlan, and Sanders, interpreted the 1945 Constitution following the current situation, not merely by referring to its original meaning, which would only result in insubstantial justice. ${ }^{41}$ Later, the Constitutional Court's decision is expected to be a decision that is responsive to the legal needs that exist in society.

Even constitutional conventions can be used to fill gaps in the legal structure of state administration. In the case of written constitutions, constitutional conventions are essential to provide rules for state administrators about habits that have grown, developed, and have been regarded as something that should not be ignored. The Constitutional Court uses the convention as one of the test stones in Decision Number 79/PUU-IX/2011. The Constitutional Court conducts judicial review in reviewing Article 10 of Law Number 39 Year 2008 concerning State Ministries that reads, "In the case of workloads requiring special handling, the President may appoint Deputy Ministers to certain Ministries, which are considered to be such articles. Contrary to Article 17 of the 1945 Constitution which states "(1) The President is assisted by state ministers, (2) The Ministers are appointed and dismissed by the President, (3) Each minister is in charge of certain affairs in government, (4) Establishment, the amendment and dissolution of the state ministry are regulated in the law ", because in Article 17 of the 1945 Constitution there is no mention of the position of Deputy Minister. In this case, the role of the convention is seen not only as a source of law, but also as a basic law that can be used as the Constitutional Court to be the legal basis in its decision. Because based on the practice of constitutionality is not the first appearance of the Deputy Minister, and what is very basic is how the actual prerogative attached to the office, which has so far been accepted and has become a constitutional convention or constitutional habit in Indonesia which is also a basic law for the President in carrying out his duties. ${ }^{42}$

In dealing with the constitutional review, the discussion should include recent developments in the minds of Constitutional Justices. According to Indonesian legal scholar Saldi Isra, there was a shift in textual thinking towards a progressive way of

39 Ibid at 12.

40 Manunggal K. Wardaya, Perubahan Konstitusi Melalui Putusan MK: Telaah Atas Putusan Nomor 138/PUU-VII/2009 (2010) 7:2 Jurnal Konstitusi at 39.

$41 \quad$ Ibid at 39.

42 Weldy Agiwinata, Konvensi Ketatanegaraan Menjadi Batu Uji dalam Pengujian Undang-Undang di Mahkamah Konstitusi (2010) 7:2 Jurnal Konstitusi at 163. 
thinking. Based on this shift, it can be understood that constitutional justice can be found by prioritizing ethical, moral, and human values that are not only found in constitutional texts. ${ }^{43}$ In line with the progression of the way of thinking of constitutional judges as reflected in each of their decisions, there is a distorted decision phenomenon. Deviations or anomalies from the decision, at first glance only about the editorial of the decision, but if the judge's way of thinking and the legal consequences formed give birth to certain legal consequences, then the anomaly needs to be understood in the context of its birth as well. Anomalous practices in MK Decisions can be found by examining the character of decisions that have developed so far. Deviations from Article 57 paragraph (2a) of Law 8/201l gave birth to conditional decisions, and/or decisions that provide substitute norms for canceled norms. ${ }^{44}$

Other evidence that the Constitutional Court dares to take a progressive stance in order to realize constitutional justice is reflected in the many positive legislative decisions, namely those that regulate. It emerged in the decade second of the Constitutional Court; from 2008 to 2013, approximately 58 decisions were favorable legislature. ${ }^{45}$ Shifting the Testing of the Law from a negative legislature is a decision that is annulled into a positive legislature, causing the existence of anomalous decisions to give a false or vague color in terms of the constitutional or unconstitutional norms. A ruling that grants the petition of the petitioner partially and rejects the petition of the petitioner in addition to the rest, which as a whole remains determined in the interpretation (interpretation) by the Constitutional Court. According to Maruarar Siahaan, the juridical substance of the decision of the Court is merely declarative, but the decision of the Court in the case of Testing Act against the Constitution has the nature of a constitutive, either in the form of the establishment of legal norms and which negates the legal norms in the provisions of legislation tested. ${ }^{46}$ An informal amendment to the 1945 Constitution is inseparable from the constitutional culture of the judge. This attitude shows that the Constitutional Court has a prominent role for which the 1945 Constitution should be applied. ${ }^{47}$

\section{ENFORCING THE 1945 CONSTITUTION THROUGH LIVING CONSTITUTION}

David A Strauss states that aA living Constitution is one that evolves, changes over time, and adapts to new circumstances, without being formally amended. This statement means that a living constitution is a developing and changing constitution. Over time, it adapts to changes

43 Nurrahman Aji Utomo, Dinamika Hubungan Antara Pengujian Undang-Undang dengan Pembentukan Undang-Undang, (2015) 12:4 Jurnal Konstitusi at 833.

44 Ibid at 833.

45 Ibid at 834-836.

46 Maruarar Siahaan, Role of the Constitutional Court in Upholding Constitutional Law, (2009) 16:3 Jurnal Hukum at 360.

47 Khairul Umam, Teori dan Metode Perubahan, Undang-Undang Dasar 1945 Melalui Tafsir Konstitusi Perspektif Budaya Konstitusi (Yogyakarta: Thafamedia, 2016) at 7. 
even if it does not undergo a formal amendment. ${ }^{48}$ Therefore, the 1945 Constitution as a basic rule in state life should be able to adjust the development of the times and the needs of the people without the need to be formally changed. By regarding the 1945 Constitution as a living constitution, it becomes the right solution in responding to the dynamics of the current state administration. It takes into account the possible political interests during the amendment of the constitution despite the legal aspects.

\section{A. Amendment through the Convention}

Wheare classifies the constitutions varying to written and unwritten constitutions. A written constitution is a constitution contained in one or several formal documents. The United States can be an example. While the unwritten constitution is a constitution that is not stated in a formal document. The United Kingdom can be a relevant example, ${ }^{49}$ as this country adopts many state administrations using state conventions. Constitutional convention is the terminology commonly known in debates regarding constitutional law and its practice. Typically, the term convention is identified with the habits or habits of state administration, when, in fact, it is different. Habit requires repetition, while convention does not. In practice, the convention is also considered as one of the ways to change what is written in the constitutional text, in accordance with good needs to ensure the operation of constitutional norms in practice. Wheare, in his book "modern constitutions," quoted by Jimly Asshiddiqie, argues many necessary changes in the working of a constitution occur without any alteration in the rules which regulate a government, whether they are strictly legal or rules of custom and convention. ${ }^{50}$ Many changes occur in the framework of implementing the constitution without absolutely changing the sound of the legal text of the provisions governing a government, but it just happens rules of custom and convention. ${ }^{51}$

In general, conventions are often interpreted as "unwritten laws "but are sometimes distinguished and not even considered as a law at all. In English, unwritten laws are usually identified with common law. Often, unwritten laws themselves are also identified with customs or customs or customs. ${ }^{52}$ All of this has the potential to confuse if it is associated with the notion of customary law or customary laws, which are not only laws in a sense (strict tense) but also require immemorial antiquity for their enforcement. Meanwhile, constitutional convention does not require such a immemorial antiquity. ${ }^{53}$

The word convention is often also used by constitutional lawyers to refer to the understanding of rules of political practice or norms arising in practices political that

\footnotetext{
48 David A Strauss, The Living Constitution, online: https://www.law.uchicago.edu/news/livingconstitution>.

49 Ellydar Chaidir, Hukum dan Teori Konstitusi (Yogyakarta: Total Media Creation, 2007) at 49-51.

50 Jimly Asshiddiqie, supra note 2 at 110.

51 Ibid at 192.

52 Ibid.

53 Ibid.
} 
are also considered binding by state administrators. However, the norm of practice itself because it is not based on written provisions, is considered not binding on the judges, if they are brought to the case by interested parties who challenge or oppose the unwritten political practices. O. Hood Philipps, Paul Jackson, and Patricia Leopold argues that the lack of judicial enforcement distinguishes conventions from laws in the strict sense. It is an essential formal distinction for the lawyer, even though the politician may not be so interested in the distinction. ${ }^{54}$

Constitutional conventions of customary law are laws that have grown up in the practice of state administration to complete, perfect, and live up to the rules of statutory law or customary law of state administration. Constitutional convention, although not as a written rule of law, its existence is recognized and implemented in the constitutional system in Indonesia. Even when the written law is unable to solve the problem, the legal concept used is the legal principle that contains moral and customary norms to be able to provide a reference for resolving the constitutional problem. ${ }^{55}$ To understand more precisely the convention, we can also relate it to the understanding that applies to the sociology of law. Concerning the binding capacity of the norm, understanding is usually distinguished; 2. usages; 2. folkways, 3. mores; and 4. customs. ${ }^{56}$ In this context, the conventions of the constitution is none other than constitutional practices that contain one of the four types of norms, inter alia, usages, folkways, mores, or customs, which are summarized in terms of constitutional usages, and constitutional practices, as well as constitutional customs or customs, state administration. ${ }^{57}$

Constitutional conventions are not only found in countries that do not recognize written constitutional documents, but also in most countries with written constitutions. In Australia and the United States, conventions state are recognized as critical legal sources in practice. For example, the procedure for electing the President and the procedure for determining the cabinet members of the United States government is largely governed by constitutional conventions, not based on written regulations. Likewise, in Indonesia, a lot of usages and practices in the administration of the state are not based on written rules, but only based on habits inherited from the past. To ensure that the substance of the 1945 Constitution or the Constitution remains alive or can be left behind, each of the 1945 Constitution regulates the amendments. In practice, formal change is no longer seen as the only way to adjust or to revive the 1945 Constitution. Amendments are always accompanied by long and complicated debates, both in political and scientific terms. Besides, amendments are often through complex procedures. Everything takes a long time. It is possible when the amendment is passed; there will be a new situation and new demands.

54 Tri Suhendra Arbani, Eksistensi Konvensi sebagai Sumber dan Praktek Ketatanegaraan di Indonesia (2016) 5:1 Jurnal Yuridika at 7.

55 Ni'Matul Huda, Hukum Tata Negara Indonesia (Jakarta: PT Raja Grafindo Persada, 2012) at 31-34.

56 Soerjono Soekanto, Sosiologi Suatu Pengantar (Jakarta: UI Publisher Foundation, Jakarta, 1975) at 75.

57 Tri Suhendra Arbani, The Existence of Convention as a Source and Practices of State Administration in Indonesia, (2016) 5:1 Jurnal Supremasi Hukum at 75. 
Dogmatically, the practice of state administration does not only give new meaning; it can even set aside the substance or rules of the 1945 Constitution. The practice of state administration is not a problem when coupled with the tradition or consistency of the constitutional system. In the light of the teachings of the constitution, the practice of state administration is intended to strengthen the joints of the constitution, such as constitutionalism, the rule of law, and democracy. One benchmark that cannot be skipped is the fundamental fundamentals of the 1945 Constitution or state. In the Indonesian context, it includes what so-called Pancasila. Thus, the practice of state administration that deliberately overrides the 1945 Constitution and the foundations of the state for a dictatorship or authoritarian rule is not a practice of state administration in the meaning of convention. ${ }^{58}$

The issuance of Decree No. X dated October 16, 1945, signed by Mohammad Hatta became one of the examples of the existing state administration convention in Indonesia. This Declaration stipulates that: ${ }^{59}$

"The Central National Committee, before the formation of the People's Consultative Assembly and the House of Representatives, was entrusted with legislative power and participated in setting broad outlines of the direction of the state. That the day-to-day work of the Central National Committee is due to the urgency of the situation carried out by a Workers' Body elected between them and responsible to the Central National Committee."

This declaration fundamentally changed the practice of the 1945 Constitution, the product of the Investigation Agency for the Preparation of Indonesian Independence. Because the Additional Rules of the 1945 Constitution state that before the People's Consultative Assembly, the House of Representatives and the Supreme Advisory Council were formed according to this Basic Law, all powers were exercised by the President with the assistance of a National Committee. This Declaration No. X was then followed by Government Announcement 14 November 1945. This information also changed the 1945 Constitution in practice. If at first the cabinet or the ministers were responsible to President Soekarno, when the announcement came out, the cabinet was directly responsible to the Prime Minister, namely Sutan Syahrir. Article 17 of the 1945 Constitution states that: 1) The President is assisted by State Ministers. 2) The ministers are appointed and dismissed by the President..$^{60}$

Thus, the example in the practice of state administration which can be regarded as a constitutional convention such constitutional practices clearly does not contradict the 1945 Constitution even on the contrary the constitutional conventions are complementary to the 1945 Constitution can be more operational to meet the future of constitutional life in accordance with the times and in accordance with the needs of a constructive and modern society. All of these examples are constitutional life accepted

58 Bagir Manan and Susi Dwi Harijanti, Memahami Konstitusi, Makna dan Aktualisasi (Jakarta: PT Raja Grafindo Persada, 2014) at 133-135.

59 Ni'matul Huda, supra note 55 at 114.

60 Wira Atma Hajri and Rahdiansyah, supra note 4 at 572. 
and obeyed even though it is not the law in the true sense. From the provisions mentioned above, it can be seen that the convention developed because of the need in the practice of state administration. Conventions can occur through a practice that repeatedly grows into an obligation that must be obeyed by the state administrators. The administration of the state is state equipment or state institutions. In the 1945 Constitution, the provisions governing institutions are quite clear.

\section{B. Amendment through Constitutional Court's Interpretation}

The Undang-Undang Dasar as a written constitution along with the values and norms of a basic unwritten law that live as a constitutional convention in the practice of daily state administration, including in the understanding of the constitution or basic law (droit constitutionnel) of a country. ${ }^{61}$ In addition to the conventions as previously explained, the enforcement of the living constitution can also be based on interpretation in the decisions of constitutional justices. It is under what Wheare states that constitutional changes can be through four methods, inter alia: (a) some primary forces; (b) formal amendments; (c) judicial interpretation; (d) usage and convention. ${ }^{62}$

Hitherto, the Constitutional Court's interpretation has made several changes to the 1945 Constitution. First, The interpretation in the Decision No. 005/PUU-IV/2006 in dealing with the review of Law No. 22 of 2004 about the Judicial Commission as the state organ outlined in the 1945 Constitution. In the decision, the Constitutional Court interpreted the meaning of the term 'judge' in Article 24B paragraph (1) of the 1945 Constitution by exempting the Constitutional Justices as part of the word 'judge.' Instead, the term should only refer to judges under the Supreme Court's administration. ${ }^{63}$ The Constitutional Court's decision substantially has changed Article 24B paragraph (1) of the 1945 Constitution from its original meaning to the textual meaning.

Another most remarkable example is the Constitutional Court's Decision Number 138/PUU-VII/2009 dealing with the review of Perpu Number 4 of 2009 revising Law Number 30 of 2002 on the Corruption Eradication Commission. The Court decided to have the power to examine the constitutionality of Perpu. In fact, Article 24C paragraph (1) of the 1945 Constitution does not include Perpu as the object to review. Rather, the constitution only outlines that the Constitutional Court has the authority to adjudicate at the first and last level whose decisions are final to review the law against the constitution...". ${ }^{64}$ The informal amendment to the 1945 Constitution, therefore, is inseparable from the constitutional culture of the judge that encouraged judges to interprets and changes the meaning of the text. This attitude shows that the

61 Jimly Asshiddiqie, supra note 6 at 29.

62 K.C. Wheare, supra note 21 at 23-50.

63 The decision of the Constitutional Court Number. 005/PUU-IV/2006 at 202-204.

64 Wira Atma Hajri and Rahdiansyah, supra note 4 at 569-570. 
Constitutional Court has a prominent role for which the 1945 Constitution should be applied. ${ }^{65}$

\section{CONCLUSION}

This paper provides a breakthrough based on existing practices, namely upholding the 1945 Constitution through a living constitution that can apply in two ways. First, it should be through the constitutional convention Indonesia has practiced this through the Declaration of Vice President Number X and the appointment of a deputy minister. Even the constitutional convention was used as a source of test stones by the constitutional judges so that it was wide open. Second, the amendment should be applied through the interpretation of the Constitutional Court. This practice is applied in several laws that have produced progressive decisions that have changed the 1945 Constitution caused by a shift in textual thinking towards a progressive way of thinking. Based on this shift, the Constitutional Court has become an institution prioritizing ethical, moral, and humanitarian values that develop in a society that is only found in constitutional texts. Suggestions that can be given at the end of the research are the state, the Government and the House of Representatives (DPR) and the related State Institutions can use the living constitution, in this case, the constitutional convention as a source in organizing the state to patch up the weaknesses of the 1945 Constitution; and constitutional justices can use the interpretation of the living constitution in interpreting the constitution.

\section{ACKNOWLEDGMENTS}

None.

\section{COMPETING INTERESTS}

The authors declare that they have no competing interests.

\section{REFERENCES}

Abu Daud Busroh, Ilmu Negara (Jakarta: Bumi Aksara, 2014).

Astim Riyanto, Teori Konstitusi (Bandung: Yapemdo, 2003).

Bagir Manan dan Susi Dwi Harijanti, Memahami Konstitusi, Makna dan Aktualisasi (Jakarta: PT Raja Grafindo Persada, 2014).

David A Strauss, The Living Constitution, https://www.law.uchicago.edu/news/livingconstitution.

Denny Indrayana, Negara Antara Ada dan Tiada (Bogor: Grafika Mardi Yuana, 2008).

65 Khairul Umam, supra note 47. 
Ellydar Chaidir \& Sudi Fahmi, Hukum Perbandingan Konstitusi (Yogyakarta: Total Media, 2010).

Ellydar Chaidir, Hukum dan Teori Konstitusi (Yogyakarta: Kreasi Total Media, 2007).

Hans Kelsen, Teori Umum Tentang Hukum dan Negara, Penerjemah: Raisul Muttaqien, Cetakan Ke VI (Bandung: Nusa Media, 2011).

Ilham Yuli, Rekonstruksi Hukum dan Ketanegaraan Indonesia (Yogyakarta: UII Press, 2016).

Irham Nugroho, Positivisme Auguste Comte: Analisa Epistimologis dan Nilai Etisnya terhadap Sains, Jurnal Cakrawala, Vol. XI, No. 2, Desember 2016.

Jimly Asshiddiqie, Hukum Tata Negara dan Pilar-Pilar Demokrasi (Jakarta: Konstitusi Pers, 2005).

Jimly Asshiddiqie, Konstitusi dan Konstitusionalisme (Jakarta: Sinar Grafika, 2011).

Jimly Asshiddiqie, Pengantar Ilmu Hukum Tata Negara (Jakarta: PT Raja Grafindo Persada, 2016).

K.C. Wheare, Konstitusi-Konstitusi Modern (Surabaya: Pustaka Eureka, 2005).

Khairul Umam, Teori dan Metode Perubahan, Undang-Undang Dasar 1945 Melalui Tafsir Konstitusi Perspektif Budaya Konstitusi (Yogyakarta: Thafamedia, 2016).

Mahfud MD, Perdebatan Hukum Tata Negara Pasca Amandemen (Jakarta: PT Raja Grafindo Persada, 2011).

Mahfud MD, Politik Hukum (Jakarta: PT Raja Grafindo Persada, 2010).

Manunggal K. Wardaya, Perubahan Konstitusi Melalui Putusan MK: Telaah Atas Putusan Nomor 138/PUU-VII/2009, Jurnal Konstitusi, Volume 7, No. 2, April 2010.

Ni’Matul Huda, Hukum Tata Negara Indonesia (Jakarta: PT Raja Grafindo Persada, 2012).

Ni'matul Huda, Perkembangan Hukum Tata Negara (Yogyakarta:UII Press, 2014).

Nurrahman Aji Utomo, Dinamika Hubungan Antara Pengujian Undang-Undang dengan Pembentukan Undang-Undang, Jurnal Konstitusi, Volume 12, No. 4, Desember 2015.

Soerjono Soekanto, Sosiologi Suatu Pengantar (Jakarta: Yayasan Penerbit UI, Jakarta, 1975).

Soetandyo, Hukum: Paradigma, Metode, dan Dinamika Masalahnya (Jakarta: ELSAM dan HUMA, 2002).

Tri Suhendra Arbani, Eksistensi Konvensi sebagai Sumber dan Praktek Ketatanegaraan di Indonesia, Jurnal Yuridika, Vol. 5, No. 1, Juni 2016.

Weldy Agiwinata, Konvensi Ketatanegaraan menjadi Batu Uji dalam Pengujian Undang-Undang di Mahkamah Konstitusi, Jurnal Konstitusi, Volume 7, No. 2, April 2010.

Wira Atma Hajri dan Rahdiansyah, Menghidupkan Undang-Undang Dasar 1945 tanpa Amandemen, Jurnal Ius Quia Iustum, No. 04, Volume 24 October 2017. 